\title{
A HEAT-BALANCE STUDY ON SØRBREEN, JAN MAYEN
}

\author{
By P. C. Dibben* \\ (Meteorological Office, Gloucester, England)
}

\begin{abstract}
The techniques and results of a heat-balance programme on Sorbreen, Jan Mayen, are presented and discussed. Estimates of $24 \mathrm{hr}$. heat-transfer totals under frontal and non-frontal weather conditions are then made. Transfer is found to be higher during frontal conditions, due to an increase in latent and to a lesser extent sensible heat transfer. Consideration of upper air temperatures and humidities suggests this higher transfer is experienced by the glacier as a whole. It is then proposed that summer rainfall totals will provide an index of frontal activity which may be used to indicate relative ablation from one summer to another. A statistical comparison of ablation measured on the glacier and rainfall recorded at the Jan Mayen meteorological station supports this suggestion.
\end{abstract}

RÉsumé. Étude du bilan énergétique du Sorbreen, Jan Mayen. On présente ici les techniques de mesure et les résultats du programme de l'étude du bilan énergétique du Sørbreen, Jan Mayen, avec leur discussion. On estime alors les totaux de transfert de chaleur pendant 24 heures dans les conditions météorologiques frontales et non-frontales. Le transfert est le plus grand pendant les conditions frontales dû à une augmentation du transfert de chaleur latente et une moindre extension du transfert de la chaleur sensible. Considérant les températures et les humidités des couches d'air élevées, il semble que le transfert le plus important est subi par le glacier dans son ensemble. Il est alors proposé que les totaux de précipitation estivale sous forme de pluie donnent un index d'activité frontale qui peut être utilisé pour indiquer l'ablation relative d'un été à un autre. Une comparaison statistique entre l'ablation mesurée sur le glacier et la chute de pluie enrégistrée à la station météorologique de Jan Mayen appuie cette suggestion.

Zusammenfassung. Wärmehaushalt-Untersuchung am Sorbreen auf Jan Mayen. Technik und Ergebnisse eines Wärmehaushaltsprogramms am Sørbreen auf Jan Mayen werden mitgeteilt und diskutiert. Daran knüpfen sich Schätzungen des gesamten 24-stündigen Wärmeaustausches bei frontalen und nicht-frontalen Wetterlagen. Bei Frontwetterlagen ergibt sich ein höherer Austausch, hervorgerufen durch die Zunahme des Austausches an latenter und-in geringerem Ausmass-auch an fühlbarer Wärme. Die Betrachtung der Lufttemperaturen und -feuchtigkeiten in höheren Lagen lässt annehmen, dass dieser höhere Austausch sich auf den gesamten Gletscher auswirkt. Es folgt der Vorschlag, die Höhe des sommerlichen Regenfalls als Index für die frontale Tätigkeit zu wählen, aus dem sich die relative Ablation von einem Sommer zum anderen herleiten lässt. Dieser Vorschlag wird durch einen statistischen Vergleich zwischen der auf dem Gletscher gemessenen Ablation und dem auf den meteorologischen Stationen von Jan Mayen registrierten Regenfall gestützt.

\section{INTRODUCTION}

The primary purpose of the 1963 Imperial College Expedition to north Jan Mayen was to continue and extend the glaciological work done by a previous Imperial College Expedition in $193^{8}$ and the two London University Expeditions in 1959 and I 96 I.

One objective of the 1963 expedition was to determine what factors are primarily responsible for the ablation of the surface of Sørbreen, and for this purpose a heat-balance programme was devised. The programme was carried out at a meteorological station established at $720 \mathrm{~m}$., near the top of the western lateral moraine of the glacier. Sørbreen drains the southern flank of the Beerenberg, a volcanic cone $2,270 \mathrm{~m}$. in height, which dominates north Jan Mayen.

\section{The Heat-balance Equation}

The mechanisms of heat transfer to the surface are:

I. Radiative transfer, the resultant of four radiation streams: (a) Incoming solar radiation (including scattered and reflected radiation); (b) Outgoing solar radiation reflected from the glacier surface; (c) Incoming long-wave radiation from the atmosphere; (d) Outgoing long-wave radiation emitted by the glacier surface.

2. Latent heat transfer as a result of condensation onto the surface.

3. Sensible heat transfer, a transfer direct from the overlying air.

* Formerly at Department of Meteorology, Imperial College of Science and Technology, London, England. 
Each term may be positive or negative. Temperature readings in the top metre or so of the surface did not differ significantly from the freezing point and hence the fourth possible transfer mechanism of conduction in the surface layer can be ignored.

When the surface is freely melting the above three terms, together with an ablation term (ablation being defined as the number of grams of ice melted in the surface layer), constitute a heat-balance equation. Denoting the ablation by $A$, the net radiative transfer by $R$, the latent heat transfer by $L$, and the sensible heat transfer by $S$, then:

$$
8 \mathrm{o} A=R+L+S \text {. }
$$

The numerical constant in the equation is the latent heat of fusion (cal. g. ${ }^{-1}$ ). In this case the units of the terms were reduced to cal. $\mathrm{cm} \cdot .^{-2}$ min. ${ }^{-1}$, although actual measurements were made over several hours (usually about five) and over a suitably large area.

\section{Short-Period Heat Transfers}

\section{Method of determination}

(1) Net radiative heat transfer. This component was determined by means of a radiation balance meter consisting of about 2,00o copper-constantan series-connected thermocouples embedded in an element whose surfaces were painted with optical black lacquer. The output from the meter was fed first into an amplifying circuit and then into a potentiometric recorder which gave a continuous registration of the net incoming radiation. To prevent heat loss by turbulent conduction from the surfaces, a method similar to that described by Suomi and Kuhn (1958) was adopted. Two air gaps $0.5 \mathrm{~cm}$. thick were formed on either side of the element by stretching polyethylene sheeting across and parallel to the surfaces. The sheeting to some extent interrupts the passage of the radiation streams, the reflection and consequent loss of solar radiation being of greater importance than that due to incomplete transmission of long-wave radiation. As a result of comparing the output of this meter with that of a standard ventilated flux plate, it seems likely that this reduction, which is a function of solar altitude, never exceeded 20 per cent.

(2) Latent heat transfer. This component was calculated from the change in mass over the period of a snow sample isolated from, but having as far as possible the same environment as, the surface of the glacier. Two such snow samples of $184 \mathrm{~cm} .^{2}$ surface area were used, each being placed in a thin, white painted, tin container. The samples of about ro $\mathrm{cm}$. in depth rested on perforated zinc platforms so that melt water was free to drain into the bottoms of the containers. Melting of the surfaces both inside and outside the containers caused the samples to become somewhat unrepresentative of the glacier surface and also resulted in the area being rather poorly defined. A second source of error lay in the deposition of water droplets from stratus clouds which, on days of light winds, exhibited pulsations in height, the upper surface passing fairly regularly through the observation point. A simple calculation with a typical cloud droplet indicates that the change in mass of a snow sample, due to such a deposition, could be of the same order as that due to condensation.

(3) Sensible heat transfer. Utilizing two expressions given by Sheppard (1958), the latent and sensible heat transfers to the surface may be written as

hence

$$
\begin{aligned}
L & =D \times 597\left(\Gamma-\Gamma_{0}\right) \text { cal. cm. } .^{-2} \mathrm{~min} .^{-1}, \\
S & =D \times 0 \cdot 24\left(\theta-\theta_{0}\right) \text { cal. cm. } .^{-2} \mathrm{~min} .^{-1}, \\
S & =\frac{L \times 0 \cdot 24\left(\theta-\theta_{0}\right)}{597\left(\Gamma-\Gamma_{0}\right)} \text { cal. cm. } .^{-2} \mathrm{~min} .^{-1} .
\end{aligned}
$$

The factor $D$ in the above equations contains a variable known as the friction velocity which causes $D$ to be a non-linearly increasing function of wind speed. It has been assumed that $D$ 
is identical in the two expressions. This is not strictly true but any resulting error is likely to be smaller than that due to uncertainty in the observed quantities. The numerical constant in equation (2) is the latent heat of vaporization of water (a vapour-liquid transfer being assumed at the melting surface), and that in equation (3) is the specific heat of dry air at constant pressure (the error introduced by ignoring the water vapour content of the air is negligible). $\theta$ and $\Gamma$ are respectively the potential temperature and humidity mixing ratio (the latter being related to the vapour pressure $e$ as follows:

$$
\Gamma=\frac{0 \cdot 622 e}{p-e},
$$

$p$ being the atmospheric pressure). The suffix o indicates a surface value.

Readings from wet- and dry-bulb thermometers (taken every I $_{5} \mathrm{~min}$. at a height of $\mathrm{I}_{40}$ $\mathrm{cm}$. above the surface) determined $\Gamma$, whilst $\theta$ was calculated from the dry-bulb temperature and the atmospheric pressure. No additional readings were required to determine $\Gamma_{\mathrm{o}}$ and $\theta_{\mathrm{o}}$ at the melting glacier surface (it being assumed that the air in immediate contact with the surface was saturated and at $\mathrm{o}^{\circ} \mathrm{C}$.). Thence with a knowledge of $L, S$ may be calculated.

Measurement of ablation. It was hoped that by determining the ablation a check could be made on the sum of the other terms in the heat-balance equation. Because a large number of samples could be satisfactorily obtained, the ablation was equated to the product of the rate of depression of the snow surface with the snow density. The results, when compared with the sum of the other terms (Table I) suggests this method underestimates the short-period ablation. In an attempt to find a reason for this underestimation, correlation coefficients were

Table I. Short-period Heat-balance Results and Prevailing Conditions

\begin{tabular}{|c|c|c|c|c|c|c|c|c|c|c|}
\hline Date & $\begin{array}{c}\text { Time } \\
\text { period } \\
\text { G.M.T. }\end{array}$ & $R$ & $L_{\text {cal }}$ & $\begin{array}{c}S \\
\mathrm{~cm} .^{-2} \mathrm{~m}\end{array}$ & $\operatorname{ain}^{-1}{ }^{-1}$ & Ablation & $\begin{array}{l}\text { Vapour } \\
\text { pressure } \\
\mathrm{mb} .\end{array}$ & $\begin{array}{l}\text { Tem- } \\
\text { perature } \\
{ }^{\circ} \mathrm{C} .\end{array}$ & $\begin{array}{l}\text { Wind } \\
\text { re speed } \\
\mathrm{m} . \mathrm{sec}\end{array}$ & Weather \\
\hline${ }_{15}$ July & $11.4^{0}-16.4^{\circ}$ & $(0.20)$ & $\begin{array}{l}0.01 \\
0.01\end{array}$ & $\begin{array}{l}0.03 \\
0 \cdot 03\end{array}$ & $\begin{array}{r}(0.24) \\
(0.24)\end{array}$ & $\left(0 \cdot I_{3}\right)$ & $6 \cdot 66$ & $2 \cdot 83$ & $3 \cdot 20$ & $\begin{array}{l}\text { Non-frontal. Small } \\
\text { amounts of high } \\
\text { cloud. Sun occa- } \\
\text { sionally obscured } \\
\text { by stratus cloud. } \\
\text { A few short inter- } \\
\text { vals of mist. }\end{array}$ \\
\hline 16 July & $11.20-16.25$ & 0.29 & $\begin{array}{r}0.01 \\
+0.00\end{array}$ & $\begin{array}{l}0 \cdot 13 \\
0 \cdot 04\end{array}$ & $\begin{array}{l}0.43 \\
0 \cdot 33\end{array}$ & $(0.22)$ & $6 \cdot 39$ & $4 \cdot 22$ & 0.95 & $\begin{array}{l}\text { Non-frontal. Sun un- } \\
\text { obscured by cloud. } \\
\text { Ci. to south and } \\
\text { Sc. below. No mist. }\end{array}$ \\
\hline I 7 July & $11.25-16.30$ & 0.10 & $\begin{array}{l}-0.01 \\
+0.00\end{array}$ & $\begin{array}{r}0.02 \\
+0.00\end{array}$ & $\begin{array}{l}0.11 \\
0.10\end{array}$ & $(0.08)$ & $5 \cdot 68$ & $2 \cdot 4^{6}$ & I $\cdot 74$ & $\begin{array}{l}\text { Non-frontal. } \frac{7}{8} \text { ths } \\
\text { medium cloud } \\
\text { above; also some } \\
\text { Ci. to north. Ex- } \\
\text { tensive Sc. below. } \\
\text { A short interval of } \\
\text { mist. }\end{array}$ \\
\hline 2 I July & $12.30-17.15$ & $(0.14)$ & $\begin{array}{l}(+0.00) \\
(+0.00)\end{array}$ & $\begin{array}{l}(0.01) \\
(0.01)\end{array}$ & $\begin{array}{l}(0 \cdot 15) \\
(0 \cdot 15)\end{array}$ & $(0.04)$ & $6 \cdot 26$ & I $\cdot 9^{2}$ & $(0 \cdot 46)$ & $\begin{array}{l}\text { Non-frontal. Exten- } \\
\text { sive Sc. above. } \\
\text { Periods of mist. }\end{array}$ \\
\hline 22 July & $11.00-16.25$ & 0.32 & $\begin{array}{l}-0 \cdot 11 \\
-0.10\end{array}$ & $\begin{array}{l}0.08 \\
0.07\end{array}$ & $\begin{array}{l}0.29 \\
0.29\end{array}$ & - & $4 \cdot 5^{1}$ & $\mathbf{1} \cdot 93$ & $4 \cdot 90$ & $\begin{array}{l}\text { Non-frontal. } \frac{1}{8} \text { th Ci. } \\
\text { at } \mathrm{I} \text {. oo } \mathrm{Z} \text { increas- } \\
\text { ing. Almost com- } \\
\text { plete overcast at } \\
\text { I6.25 } \mathrm{Z} \text { of Ci.-St. } \\
\text { A few short inter- } \\
\text { vals of mist. }\end{array}$ \\
\hline
\end{tabular}




\begin{tabular}{|c|c|c|c|c|c|c|c|c|c|c|}
\hline $\begin{array}{l}\text { Date } \\
\text { I963 }\end{array}$ & $\begin{array}{c}\text { Time } \\
\text { period } \\
\text { G.M.T. }\end{array}$ & $R$ & ${ }_{\text {cal. }}$ & $\underset{\mathrm{m} \cdot .^{-2} \mathrm{~min}}{S}$ & $\mathrm{n}^{-\mathrm{Sum}}$ & Ablation & $\begin{array}{c}\text { Vapour } \\
\text { pressure } \\
\text { mb. }\end{array}$ & $\begin{array}{c}\text { Tem- } \\
\text { perature } \\
{ }^{\circ} \mathrm{C} \text {. }\end{array}$ & $\begin{array}{l}\text { Wind } \\
\text { speed } \\
\mathrm{m} . \mathrm{sec}\end{array}$ & Weather \\
\hline 25 July & $11.05-16.30$ & 0.17 & $\begin{array}{l}(+0.00) \\
(+0.00)\end{array}$ & - & - & - & - & 0.10 & $\mathrm{I} \cdot 45$ & $\begin{array}{l}\text { Nonfrontal. } \frac{3}{8} \text { ths Ci.- } \\
\text { an-d Ac. Fairly ex } \\
\text { tensive Sc. below. } \\
\text { Periods of mist. }\end{array}$ \\
\hline 28 July & $12.00-17 \cdot 10$ & 0.26 & $\begin{array}{l}0.06 \\
0.07\end{array}$ & $\begin{array}{l}0.10 \\
0.12\end{array}$ & $\begin{array}{l}0 \cdot 4^{2} \\
0 \cdot 45\end{array}$ & $0 \cdot 30$ & $8 \cdot 4^{6}$ & $7 \cdot 08$ & $4 \cdot 01$ & 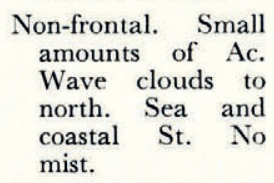 \\
\hline 29 July & 1 1.30-16.45 & 0.27 & $\begin{array}{l}0.02 \\
0.03\end{array}$ & $\begin{array}{l}0.04 \\
0.06\end{array}$ & $\begin{array}{l}0 \cdot 33 \\
0 \cdot 36\end{array}$ & 0.29 & $7 \cdot 4^{\circ}$ & $5 \cdot 06$ & $1 \cdot 80$ & $\begin{array}{l}\text { Non-frontal. Sun at } \\
\text { times partially ob- } \\
\text { scured by Ci. and } \\
\text { St. cloud. No mist. }\end{array}$ \\
\hline I August & I 1.40-16.45 & $0 \cdot 3^{2}$ & $\begin{array}{r}(0.12) \\
(0.11) \\
(+0.00)\end{array}$ & $\begin{array}{l}(0.24) \\
(0.22) \\
(0.01)\end{array}$ & $\begin{array}{l}(0 \cdot 68) \\
(0 \cdot 65) \\
(0 \cdot 33)\end{array}$ & 0.19 & $6 \cdot 77$ & $2 \cdot 13$ & $1 \cdot 04$ & $\begin{array}{l}\text { Non-frontal. } \frac{3}{8} \text { ths Ci. } \\
\text { mainly to north. } \\
\text { Extensive Sc. } \\
\text { below. Periods of } \\
\text { mist, "wet" during } \\
\text { final go min. }\end{array}$ \\
\hline 2 August & $10.15^{-1} 5.30$ & $0 \cdot 33$ & $\begin{array}{r}0.01 \\
-0 \cdot 00\end{array}$ & $\begin{array}{l}0.05 \\
0.01\end{array}$ & $\begin{array}{l}0.39 \\
0 \cdot 34\end{array}$ & 0.25 & $6 \cdot 5^{2}$ & $4 \cdot 50$ & $0 \cdot 6 \mathrm{I}$ & $\begin{array}{l}\text { Non-frontal. } \\
\text { medium and high } \\
\text { cloud. A few short } \\
\text { intervals of mist. }\end{array}$ \\
\hline 3 August & $10.15^{-15.50}$ & $0 \cdot 35$ & $\begin{array}{l}0.01 \\
0.02\end{array}$ & $\begin{array}{l}0.03 \\
0 \cdot 05\end{array}$ & $\begin{array}{l}0.39 \\
0 \cdot 4^{2}\end{array}$ & 0.29 & $7 \cdot 05$ & $4 \cdot 24$ & I. 50 & $\begin{array}{l}\text { Non-frontal. } \frac{3}{8} \text { ths Ci. } \\
\text { Fairly extensive Sc. } \\
\text { below. A few short } \\
\text { intervals of mist. }\end{array}$ \\
\hline August & $10.20-15.55$ & 0.08 & $\begin{array}{l}(0.43) \\
(0.40) \\
(0.10)\end{array}$ & $\begin{array}{l}(0 \cdot 6 o) \\
(o \cdot 56) \\
(0 \cdot 13)\end{array}$ & $\begin{array}{l}(\mathrm{I} \cdot \mathrm{I} \mathrm{I}) \\
(\mathrm{I} \cdot 04) \\
(0 \cdot 3 \mathrm{I})\end{array}$ & 0.23 & $7 \cdot 88$ & $4 \cdot 06$ & $5 \cdot 70$ & $\begin{array}{l}\text { Frontal. Cloudy } \\
\text { rather misty. } \\
\text { Periods of mainly } \\
\text { light rain. Rain- } \\
\text { fallo. } 7 \text { mm. (Prob- } \\
\text { ably underesti- } \\
\text { mated due to effect } \\
\text { of wind.) }\end{array}$ \\
\hline
\end{tabular}

\section{Notes on TABLE I}

(I) Rounding off of values to the second decimal place has resulted in entries such as $+0 \cdot 00$.

(2) For the $L$ and $S$ transfers the two values corresponding to the two snow samples are given.

(3) Brackets indicate values which are not considered as reliable as those without brackets for the reasons given below.

\section{Date Element Reason}

I5 July $R$ Due to instrumental difficulties part of the radiation record is considered unreliable.

Ablation Estimate based on only one measurement of surface depression.

I6 July Ablation Estimate based on only one measurement of surface depression.

17 July Ablation Estimate based on only one measurement of surface depression.

2 I July Ablation Estimate based on only one measurement of surface depression.

$R$ Radiation term estimated from "spot" readings taken every 15 min. from a calibrated galvanometer.

$L \quad$ Periods of mist make this term rather uncertain.

$S \quad S$ derived from $L$, therefore also rather uncertain.

25 July $L \quad$ Periods of mist make this term somewhat uncertain.

I August $L \quad$ Periods of mist make this term somewhat uncertain.

$\begin{array}{lll} & S & S \text { derived from } L \text { and therefore also rather uncertain. } \\ \text { 4 } & L & \text { Periods of light rain make this term rather uncertain. }\end{array}$

4 August $\quad L \quad$ Periods of light rain make this term rather uncertain.

(4) It should also be pointed out that the temperature and vapour-pressure values for I 5, I6, 2 I July and 4 August have been obtained from thermohygrograph charts and, although the instrument was frequently checked with wet- and dry-bulb temperature readings, the values may be somewhat unreliable, as may the corresponding sensible-heat transfer terms. 
(5) The additional values in brackets for the elements $L$ and $S$ for 1 and 4 August occurring below the main entries, are estimated values using equations (2) and (3), and an estimate of $D$ derived from an empirical relationship between the actual wind speed $v \mathrm{~cm}$. sec. ${ }^{-1}$ and the friction velocity $V$. The relationship was obtained by fitting a linear regression equation to values of wind speed and friction velocity. The friction velocity was calculated from factor $D$ whose value was derived via equation (2) for periods for which $L$ and $\left(\Gamma-\Gamma_{0}\right)$ were available. The relationship found by this procedure was

$$
V=0.083 v-3.6 \mathrm{~cm} . \text { sec. }^{-1}
$$

(6) Wind speeds refer to a height of $180 \mathrm{~cm}$. above the surface.

Wind speed for 21 July derived from estimated values and one anemometer reading.

derived between ablation error (calculated ablation minus measured ablation) and each of the variables $R, L$ and $S$. The values were taken from Table I, although data for I5, 2 I, 22 and 25 July were not used, and the estimated values of $L$ and $S$ were used for I and 4 August. The correlation coefficient between the ablation error and the net incoming radiation, $R$, was positive and very nearly significant at the 5 per cent level, but the two other coefficients were considerably less. The small coefficient involving the latent-heat transfer implies that the mass change at the surface resulting from evaporation or condensation has in this case a negligible effect on the rate of depression of the glacier surface and can be ignored. The correlation coefficients were also derived using the results of Adkins (1958) for Salmon Glacier, British Columbia (where similar techniques for measuring $R$ and $A$ were used, and also over short time periods). The correlation between $R$ and the ablation error was significant at the I per cent level, whilst the other two coefficients were again considerably smaller. This suggests that in each case either the radiation income was overestimated by some factor or that with increasing radiation income the measured ablation was increasingly underestimated. This could perhaps be explained as a result of sub-surface melting with a large radiation income, which over a short time period does not give rise to an equivalent depression of the surface or a decrease in density of the surface layer (the melt water being largely retained). A more refined method of ablation measurement which attempted to take into account the change in water content of the snow surface was unsuccessful, as was the measurement of melt water percolating through the surface. In each case the variable structure of the snow surface was probably responsible for the inconsistent results.

\section{Site of determination}

A Stevenson screen was set up near the meteorological station, about $30 \mathrm{~m}$. north of the moraine on a horizontal snow surface. To the north the surface rises quite rapidly in a series of wide but shallow steps, whilst $400 \mathrm{~m}$. to the west a nunatak rises steeply to $840 \mathrm{~m}$. To the east the surface falls a little to the main glacier stream. The radiation-balance meter was supported horizontally about $130 \mathrm{~cm}$. above the surface by a light beam $\mathrm{I} 50 \mathrm{~cm}$. long attached to the back of the screen. The condensation and ablation determinations were carried out within a few metres of this point.

\section{Results of the short-period determination of heat-transfer terms}

The heat transfers found on each occasion and the prevailing conditions are given in Table I. The mean values of the transfer components and the percentage contribution of each to the total have been calculated and are given below.

$\begin{array}{lcccc}\quad \text { Transfer } & R & L & S & \text { Sum } \\ \begin{array}{l}\text { Mean value } \\ \text { (cal. cm. }{ }^{-2} \text { min. }{ }^{-1} \text { ) }\end{array} & 0 \cdot 26 & 0 \cdot 0 \text { I } & 0 \cdot 06 & 0.33 \\ \text { Percentage of total } & 78 & 4 & \text { I } 8 & \end{array}$


All occasions for which the three terms are available have been used in the calculation. Values in brackets have not been included except for the estimates of $L$ and $S$ for I and 4 August.

From Table I it is seen that 4 August is somewhat different both in the transfer terms and in the prevailing conditions. This period has been classified as frontal because it is characterized by a persistent cloud cover, periods of rain (implying thick, medium cloud layers), only a small variation in temperature and incoming net radiation, and a relatively high wind speed. Excluding this date from the above calculation yields:

$\begin{array}{lcccc}\quad \text { Transfer } & R & L & S & \text { Sum } \\ \begin{array}{l}\text { Mean value } \\ \text { (cal. cm. } .^{-2} \text { min. }{ }^{-1} \text { ) }\end{array} & 0.28 & 0.00 & 0.05 & 0.33 \\ \text { Percentage of total } & 85 & 0 & \text { I5 } & \end{array}$

For 4 August the percentage contribution of each term to the total is:

$\begin{array}{cccc}\text { Transfer } & R & L & S \\ \text { Percentage of total } & 26 & 3^{2} & 4^{2}\end{array}$

When considering these values it should be borne in mind that they are the result of measurement over a period of $5 \mathrm{hr}$. or so and are not daily estimates.

It can be seen from Table I that the high transfer sum on days of non-frontal weather is due to a high value of $R$. $R$ also showed a dependence on solar altitude, and the occurrence of snow-surface temperatures often several degrees below $0^{\circ} \mathrm{C}$. during the "night" implies a marked diurnal variation in the transfer sum on such occasions, with a negative period.

In contrast, the radiation record for 4 August suggests that during frontal weather the dependence on the solar altitude is very much smaller and hence only a small diurnal variation in the transfer sum would be expected. This conclusion is supported by the fact that on such occasions snow-surface minimum temperatures did not fall below $0^{\circ} \mathrm{C}$.

It is thus of some interest to estimate the magnitudes of the heat transfers over a period of $24 \mathrm{hr}$. under conditions of frontal and non-frontal weather. The method of estimation and the results are given in the next section together with a qualitative discussion of the variation of the transfers with height.

Estimates of Heat Transfers over a Period of $24 \mathrm{hr}$.

Method

Estimates for the two weather types of non-frontal and frontal conditions are based on I6 July and 4 August, respectively.

$x 6$ Fuly 1963

(a) Net incoming radiation, $R$. This component was determined from an equation of the form

$$
R=m \sin ^{2} \alpha+n \sin \alpha+b \text { cal. cm. } .^{-2} \min .^{-1},
$$

where $m, n$ and $b$ are constants and $\alpha$ is the mean solar altitude. With $\alpha=0, R=b$, i.e. the net incoming long-wave radiation. Assuming snow to be a black body for long-wave radiation, the emitted radiation from the surface may be calculated knowing its absolute temperature. For a melting surface the value is $0.460 \mathrm{cal} . \mathrm{cm} . .^{-2} \mathrm{~min} .{ }^{-1}$. The incoming long-wave radiation from the atmosphere, $R_{L}$, may be calculated under conditions of clear skies from an empirical relationship derived by Swinbank ( 1963$)$ and which may be written:

$$
R_{L}=0.072 \times 10^{-14} T^{6} \text { cal. cm. } .^{-2} \mathrm{~min}^{-1},
$$


$T$ being the absolute air temperature at screen level. The value of $b$ (i.e. $R_{L}-0 \cdot 460$ ), determined for a period near mid-day agreed to within 5 per cent with that given by Elsasser's radiation chart (see Haltiner and Martin, I957), using the i 2.00 G.M.T. upper air sounding at the Jan Mayen meteorological station. The value of $b$ was calculated using mean hourly values of screen temperature and estimated surface temperatures. The average value found for the $24 \mathrm{hr}$. was $b=-0 \cdot 118 \mathrm{cal} . \mathrm{cm} .^{-2} \mathrm{~min} .^{-1}$. Since the variation in $b$ was small compared with changes in terms containing $\sin \alpha, b$ was assumed to be constant with this value. The constants $m$ and $n$ were then determined by the method of least squares, using values of $R$ averaged over periods of $30 \mathrm{~min}$. (obtained from the net radiometer trace) and corresponding values of $\sin \alpha$ given by the Nautical Almanac tables for 1963 , knowing the time of observations. The resulting equation was

$$
R=\mathrm{I} \cdot 62 \sin ^{2} \alpha-0 \cdot 3 \mathrm{I} \sin \alpha-0 \cdot \text { I } 18 \text { cal. } \mathrm{cm} .^{-2} \mathrm{~min} .^{-1} .
$$

The net incoming radiation over a period of $24 \mathrm{hr}$. was calculated using values of $\alpha$ relative to a horizontal surface (actual solar altitude) and also effective values of $\alpha$, taking into account the slope of the glacier surface.

(b) Latent heat transfer, L. Re-arrangment of equation (2) gives

$$
D=\frac{L}{597\left(\Gamma-\Gamma_{\mathrm{o}}\right)} \mathrm{g} . \mathrm{cm} .^{-2} \mathrm{~min} .^{-1} .
$$

Substitution of the value of $L$ and the mean value of $\left(\Gamma-\Gamma_{\mathrm{o}}\right)$ found during the heat-balance programme of 16 July gives a value of $0 \cdot 08 \mathrm{I} 6$ for $D$. It was assumed that this value remained unchanged throughout the $24 \mathrm{hr}$. Mean values of $\left(\Gamma-\Gamma_{\mathrm{o}}\right)$ were calculated from the barothermohygrograph traces and estimated surface temperatures, and were substituted in equation (2).

(c) Sensible heat transfer, $S$. The value of o.081 6 was again taken for $D$ and mean hourly values of $\left(\theta-\theta_{0}\right)$ substituted into equation (3).

${ }_{4}$ August ${ }_{196}{ }_{3}$

(a) Net incoming radiation, $R$. This component was calculated from an equation of the form

$$
R=m \sin \alpha+b \text { cal. cm. } .^{-2} \min .^{-1} .
$$

The value of $b$ was obtained from Elsasser's radiation chart, using the I 2.oo G.M.T. upper-air sounding and observations of the cloud height on the glacier. The value of +0.032 cal. cm..$^{-2}$ min..$^{-1}$ thus found was assumed to be constant throughout the $24 \mathrm{hr}$. The constant $m$ was then derived by substituting in equation (9) the mean value of $R$ and $\sin \alpha$ during the period of observation. The resulting equation was

$$
R=0 \cdot 06 \sin \alpha+0 \cdot 032 \text { cal. cm. }{ }^{-2} \min ^{-1} .
$$

Since the incoming solar radiation will be mainly diffuse under frontal weather conditions, the slope of the surface was not considered in calculating the net incoming radiation over the $24 \mathrm{hr}$.

(b) Latent and sensible heat transfers, $L$ and $S$. The value of $D$ in equations (2) and (3) was obtained as described in the explanatory notes to Table I, and the value of $0^{\cdot} \mathrm{I} 397$ g. $\mathrm{cm} . .^{-2}$ min..$^{-1}$ was assumed constant throughout the $24 \mathrm{hr}$. Mean hourly values of $\Gamma$ and $\theta$ were obtained from the barothermohygrograph traces, whilst the surface values were those appropriate to a melting snow surface at all times. 
Results

The $24 \mathrm{hr}$. heat-transfer estimates are given in Table II. Also given are ablation values determined from the depression of the snow surface at a single stake and an average snow

Table II. Estimates of $24 \mathrm{hr}$. Heat Transfers for Frontal and Non-frontal Conditions at $720 \mathrm{~m}$.

\begin{tabular}{|c|c|c|c|c|c|c|c|}
\hline & & $R$ & $L$ & $S$ & Sum & \multirow{2}{*}{\multicolumn{2}{|c|}{$\begin{array}{c}\text { Ablation } \\
80(136) * \mathrm{cal} . \mathrm{cm} .^{-2}\end{array}$}} \\
\hline I6 July 1963 (non-frontal) & (A) & $5^{8}$ & 4 & 79 & I4 I & & \\
\hline \multirow[t]{2}{*}{ Percentage of total } & & $4^{I}$ & 3 & $5^{6}$ & & & \\
\hline & (B) & 156 & 4 & 79 & 239 & & cal. $\mathrm{cm} .^{-2}$ \\
\hline Percentage of total & & $6_{5}$ & 2 & 33 & & & \\
\hline 4 August ${ }^{96} 63$ (frontal) & (A) & 71 & I 14 & 133 & $3^{18}$ & 300 & cal. cm..$^{-2}$ \\
\hline Percentage of total & & 22 & 36 & $4^{2}$ & & & \\
\hline
\end{tabular}

(A) Actual solar altitude. (B) Effective solar altitude.

* This value refers to 2 August 1963 as explained in the text.

density of $0.50 \mathrm{~g} . \mathrm{cm} .{ }^{-3}$. It may be seen that the correspondence between calculated and measured ablation is quite good on 4 August but it is poor on 16 July. The relatively small measured ablation on the latter date is probably partly the result of the ablation stake (which had been inserted only two days before) working into the snow surface. The stake was later re-set down to the glacier ice and the ablation on 2 August, when conditions were similar to I6 July, came to $136 \mathrm{cal} . \mathrm{cm} .^{-2}$.

Therefore, the results given in Table II can perhaps be regarded as giving an indication of the magnitudes of the heat-transfer components. However, variation in the magnitudes will undoubtedly occur due to differences within the two weather types on different occasions, and there will also be a seasonal variation particularly in the net incoming radiation under non-frontal conditions.

Table II shows that:

(I) In non-frontal weather the southward slope of about $\mathrm{I}^{\circ}$ of the glacier surface causes the net incoming radiation to be more than double that on a horizontal surface.

(2) In non-frontal weather the latent-heat transfer is negligible.

(3) There is a considerable increase (of the order of 30 per cent) in the heat transfer to the surface in frontal as opposed to non-frontal conditions. The increase is mainly in the latentheat transfer and to a lesser extent in the sensible-heat transfer. The radiative transfer to a horizontal surface is also increased but only to a small extent.

\section{Variation of the Transfer Terms with Altitude}

Latent and sensible heat transfers

Before the altitudinal variation of the $L$ and $S$ transfer terms can be considered, it is first necessary to estimate the lapse of temperature and humidity mixing ratio with height. Observations were taken only at an altitude of $720 \mathrm{~m}$. on the glacier and so recourse has to be made to the upper-air soundings taken twice daily at the meteorological station (about $20 \mathrm{~km}$. to the south-west). To determine the degree of relationship between temperature and humidity mixing ratio in the free air and on the glacier, the relevant correlation coefficients were determined for an altitude of $720 \mathrm{~m}$. and are given, together with mean values, in Table III. In this qualitative investigation the actual temperature rather than the potential temperature will be considered for simplicity.

The four correlation cocfficients in Table III are all significant at the I per cent level, but the auto-non-independence of the data will reduce to some extent the statistical significance of the coefficients. As may be seen, the temperature on the glacier tends to be a little higher 
by day and a little lower by night than the corresponding temperature in the free air, whilst the mixing ratio is slightly higher on the glacier, particularly by day. There seems no reason why similar relationships should not obtain at other altitudes.

Table III. Relationship between Temperature and Humidity Mixing Ratio at 720 m. in Free Air and on the Glacier

Time

Temperature (Mean values in ${ }^{\circ} \mathrm{C}$.)

Humidity mixing ratio (Mean values $\times 10^{3}$ )

\section{Correlation between} glacier and free air

oo. $00 \mathrm{Z} \quad 12.00 \mathrm{Z}$

$+0 \cdot 90+0 \cdot 79$

$+0.90+0.78$

$$
\text { Glacier Mean values } \text { Free air }
$$

$\begin{array}{llll}00.00 \mathrm{Z} & 12.00 \mathrm{Z} & 00.00 \mathrm{Z} & 12.00 \mathrm{Z}\end{array}$

$2 \cdot 8 \quad 3 \cdot 6$

$3 \cdot 1$

$4 \cdot 7 \quad 4 \cdot 8$
$2 \cdot 8$

$4 \cdot 5$
Number of observations $00.00 \mathrm{Z} \quad 12.00 \mathrm{Z}$ I2 II

9
I I

II

Between 14 July and 30 August 23 temperature and 20 humidity mixing ratio ascents were suitable for classification as frontal or non-frontal. The criterion for frontal conditions was generally that continuous moderate rain should have been reported by the meteorological station within $3 \mathrm{hr}$. either side of the time of ascent. In the two doubtful cases where this condition was not satisfied, a decision was made in the light of observations at the glacier station. With an absence of frontal clouds, ascents were classified as non-frontal. The final classification was i frontal temperature ascents and 8 frontal mixing ratio ascents. From each ascent the temperature $(C)$ and/or mixing ratio were estimated at intervals of $250 \mathrm{~m}$., from the surface (sea-level) to $2,000 \mathrm{~m}$. The mean values $\left(C\right.$ and $\left.\left(\overline{\Gamma-\Gamma_{0}}\right)\right)$ at each level were then calculated (no distinction being made between day and night ascents) and the results are shown in Figure I. The values plotted are for temperature $0 \cdot 24 \bar{C}$ and for mixing ratio

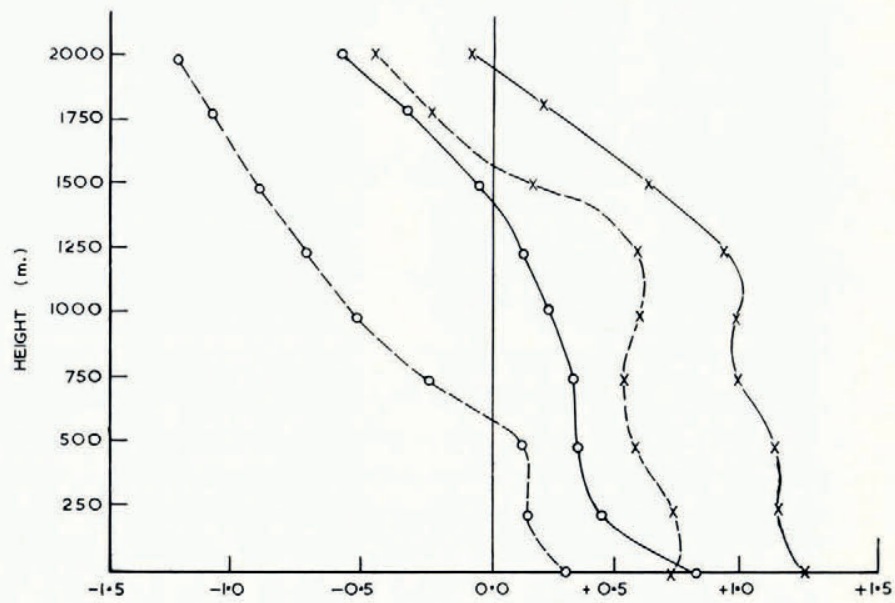

Fig. I. Altitudinal variation of $0 \cdot 24 \bar{C}$ and $597 \overline{\left(\Gamma-\Gamma_{0}\right)}$ under frontal and non-frontal conditions

$\times \longrightarrow$ Values of $0 \cdot 24 \bar{C}$ under frontal conditions.

$\times-----\times$ Values of $597 \overline{\left(\Gamma-\Gamma_{0}\right)}$ under frontal conditions.

$\bigcirc$ Values of $0 \cdot 24 \bar{C}$ under non-frontal conditions.

$\bigcirc-----\bigcirc$ Values of $597 \overline{\left(\Gamma-\Gamma_{0}\right)}$ under non-frontal conditions.

$C$ is the free-air temperature $\left({ }^{\circ} \mathrm{C}\right.$.).

$\Gamma$ is the free-air humidity mixing ratio.

$\Gamma_{\mathrm{o}}$ is the humidity mixing ratio at a melting snow surface (a function of altitude).

The factors 0.24 and 597 convert the values of $\bar{C}$ and $\overline{\left(\Gamma-\Gamma_{0}\right)}$ to heat transfer in cal. g. ${ }^{-1}$ 
$597 \overline{\left(\Gamma-\Gamma_{\mathrm{o}}\right)}, C$ and $\Gamma$ referring to the free air, whilst $\Gamma_{\mathrm{o}}$ is the value for a melting snow surface at the appropriate altitude. Thus from equations (2) and (3), and from the relation between conditions in the free air and on the glacier, the direction and magnitudes of the latent- and sensible-heat transfers are indicated by the displacement of the lines from the zero ordinate (this will not be so should the surface be frozen). A direct comparison of heat transfers between frontal and non-frontal conditions is possible from Figure $\mathrm{I}$, if equality of wind speeds is assumed. However, speeds were generally greater (and hence the value of $D$ larger) in frontal conditions, and this should be considered when making such a comparison.

Even assuming equality of wind speeds, it is seen from Figure $\mathrm{I}$ that for the glacier as a whole the latent- and sensible-heat transfers to the surface are greater under frontal conditions than under non-frontal ones. Under non-frontal conditions the probability of the sum $(L+S)$ becoming negative increases relatively rapidly with height and will be negative on the average above about $900 \mathrm{~m}$. The transfers under frontal conditions, on the other hand, remain fairly constant with height up to $\mathrm{I}, 25^{\circ} \mathrm{m}$. and the sum only becomes negative above about $\mathrm{I}, 75^{\circ} \mathrm{m}$.

\section{Radiative transfer}

Under non-frontal conditions at altitudes greater than about $700 \mathrm{~m}$. cloud amounts are generally small, and due to the increasing southerly slope of the glacier an increase in the net incoming radiation over $24 \mathrm{hr}$. would be expected with height. The resulting greater ablation would, however, be effectively reduced at higher levels by the re-freezing of melt water draining to areas receiving a smaller solar radiation income (for example, crevasses or areas of lesser slope) due to the negative $(L+S)$ sum. Under frontal conditions the variation of incoming radiation with height is likely to be small up to about $\mathrm{I}, 250 \mathrm{~m}$., thence decreasing but probably remaining positive except perhaps at the highest levels. However, as at $720 \mathrm{~m}$. the $24 \mathrm{hr}$. radiative transfer for frontal conditions will be smaller than that for non-frontal conditions.

During non-frontal conditions a persistent cloud layer exists over the glacier with an upper surface at about $700 \mathrm{~m}$. Below this level the difference in radiative transfer during frontal and non-frontal weather is perhaps small. In each case there is a reduction in incoming solar radiation which, due to the relative thinness of the non-frontal cloud, will be relatively small under these conditions, and an increase in incoming long-wave radiation which will be relatively large during frontal weather due to higher temperatures. However, the latent- and sensible-heat transfers will, as above $700 \mathrm{~m}$., increase on the average from non-frontal to frontal weather types.

The above discussion suggests that the increased heat transfer found at $720 \mathrm{~m}$. during frontal weather is experienced by the glacier as a whole. Since summer precipitation at Jan Mayen is mainly of frontal origin, the summer rainfall totals from year to year will provide an index of the frequency of frontal conditions and hence an indication of the relative ablation from one summer to another. Furthermore, it might be expected that north-facing glaciers would be more sensitive than Sørbreen to this index, since for these glaciers the incoming radiation during non-frontal conditions will be considerably reduced.

\section{Evidence of a Relationship between Rainfall and Ablation on Sørbreen}

To study the flow of the glacier, stakes were set into the surface at $300,420,700,900$ and I,500 m. above sea-level. At each level 5 stakes were set at approximately equal distances across the glacier in a line normal to the longitudinal axis of the glacier (an exception was at I,500 m., where only 3 stakes were used.)

Each line was visited at fairly regular intervals and the depression of the glacier surface since the previous observation was determined at each stake. A mean value of the depression was then derived for each line, and when this was multiplied by an assumed surface density it 
gave a representative value for the ablation at the altitude of the line during the period between observations. To eliminate the effect of differing time periods, the ablation was calculated in units of grams of ice melted per day. To eliminate the effect of altitude the value for each period was divided by the mean value over the entire period for the line. The final result was a reasonable number ( 16 ) of ablation values independent of height and length of the period, but referring (except for three values) to different time periods. For each time period the total rainfall measured at the meteorological station on south Jan Mayen was determined and then divided by the length of the period in days. The correlation between the two variables, $x$ and $y$, was then calculated and found to be

$$
r_{x y}=+0 \cdot 63
$$

where $x$ is the variable: grams of ice melted per day over limited periods at some altitude divided by the number of grams of ice melted per day over the whole period at the same altitude, and $y$ is the variable: millimetres of rainfall per day over the limited period.

The value of the correlation coefficient is significant at the I per cent level, indicating that there is a tendency during the months of July and August for high rates of rainfall to be associated with relatively high values of ablation over the glacier as a whole. This result is in agreement with the conclusion reached from a consideration of the heat-transfer estimates.

\section{Acknowledgements}

The expedition is indebted to numerous individuals and organizations, the latter including the North Atlantic Treaty Organization, Mount Everest Foundation, Royal Geographical Society and Norsk Polarinstitutt. As regards work described in the earlier part of this paper the advice of Professor P. A. Sheppard and Mr. K. Bignell, of the Department of Meteorology, Imperial College of Science and Technology, is much appreciated. I also wish to thank P. H. Draper and W. N. Whaley for assistance in the field, and J. W. Sheard, the leader of the expedition, for helpful discussion and correction of the manuscript.

MS. received 26 March 1965

\section{REFERENCES}

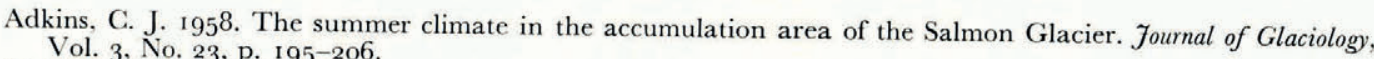
altiner, 3, No. 23, p. 195-206.

Haltiner, G. J., and Martin, F. L. 1957. Dynamical and physical meteorology. New York, McGraw-Hill.

Sheppard, P. A. 1958. Vertical transfer through the atmosphere. Quarterly Journal of the Royal Meteorological Society, Suomi, V. E., and

Swinbank, W. C. I66. 6 , I Vol. 89 , No. 381, p. 339-48. 